\title{
8
}

\section{PRANATA MANGSA DAN BUDAYA KEARIFAN LINGKUNGAN}

\author{
Supardiyono Sobirin
}

\begin{abstract}
Pranata mangsa is a traditional calendar about the rules of the season which has long been known primarily by the farming community in Java. This calendar is based on pseudo-circulation of the sun, which in the past was a reliable guide for farmers to schedule farming in the rice fields. Along with the progress of civilization of life, understanding of pranata mangsa has faded a lot, among other things because of environmental changes due to population growth, land use change, climate anomalies, and modernization of life. Although pranata mangsa has experienced many deviations, it is assumed that it can still be saved as a very wise and valuable ancestral heritage. One of the benefits is as a cultural aid in preserving the environment, and as a basis for understanding the current season's forecasting technology. A hope that pranata mangsa culture can be revived, namely if the concept of development is carried out on the basis of consistent ecological sustainability, with integrated support in the form of political will, educational will, and cultural will, and integrating traditional wisdom of pranata mangsa with modern technology.
\end{abstract}

Keywords: pranata mangsa, guide for farmers, deviations, can be saved, modern technology

\section{PENDAHULUAN}

Pranata mangsa adalah kalender tradisional tentang aturan musim yang telah lama dikenal terutama oleh masyarakat petani di Pulau Jawa. Kalender ini merupakan kalender berbasis pere-daran semu matahari, yang pada zamannya meru-pakan pedoman yang andal bagi para petani un-tuk jadwal bercocok tanam di sawah.

Pada tahun 1950-an hingga 1960-an, pranata mangsa ini dipakai sebagai bahan ajar di Sekolah Rakyat atau Sekolah Dasar di daerah sekitar Yogyakarta dan Surakarta. Tulisan ini mencoba menggali kembali, memberikan masukan dan saran tentang pemanfaatan pranata man-gsa di masa sekarang dan yang akan datang, terkait dengan perubahan-perubahan lingkungan yang terjadi.

Walaupun pranata mangsa ini telah banyak mengalami penyimpangan-penyimpangan ka-rena adanya perubahan iklim dan modernisasi ke-hidupan, namun diasumsikan bahwa pranata ma-ngsa ini masih bisa diselamatkan sebagai warisan nenek moyang yang sangat arif dan berharga. Salah satu manfaat adalah sebagai alat bantu bu-daya dalam melestarikan lingkungan hidup, dan sebagai dasar untuk memahami teknologi prak-iraan musim yang saat ini semakin maju.

Banyak tulisan yang mengupas tentang pranata mangsa, sebagian menginginkan kalender ini untuk tetap dilestarikan dan dimanfaatkan, tet-api sebagian yang lain mengatakan bahwa ka-lender ini telah usang dan tidak cocok lagi dengan situasi masa kini. Bahkan ada yang menganggap bahwa pranata mangsa ini telah merupakan klenik dan primbon.

Metode kajian untuk membahas pranata mangsa ini menggunakan analisis data sekunder dan data primer, sehingga diharapkan dapat menjadi masukan-masukan baru untuk memperbaiki konsep pranata mangsa sesuai kekinian.

\section{DASAR TEORITIS}

Teori-teori yang mendasari pembahasan antara lain yaitu bahwa kalender ini berbasis 
peredaran semu matahari yang bergeser ke utara dan ke selatan setiap tahun. Bila matahari begeser ke utara dan berada di utara khatulistiwa, artinya musim kemarau. Sebaliknya bila matahari berge-ser ke selatan dan berada di selatan kha-tulistiwa, artinya musim hujan. Bila matahari berada di sekitar khatulistiwa, artinya musim pancaroba, yang terbagi menjadi dua, yaitu pan-caroba men-jelang musim penghujan dan pancaroba menje-lang musim kemarau. Melihat posisi Pulau Jawa yang terletak posisi 5o54'08" - 8o50'20" Lin-tang Selatan dan relatif sejajar dengan garis khat-ulistiwa, maka diduga bahwa pranata mangsa hanya berlaku di Pulau Jawa, mungkin juga hingga Pulau Bali (Sobirin, 2011).

Kalender pranata mangsa mulai dikaitkan dengan kalender masehi gregorian atas ketetapan Sri Paduka Susuhunan Paku Buwono VII dari Kerajaan Surakarta pada tanggal 22 Juni 1855. Beliau berkeinginan memberi kepastian kepada rakyatnya yang rupa-rupanya mulai bingung, ka-rena pada waktu itu di masyarakat terdapat ba-nyak macam kalender, yaitu saka, pawukon, pra-nata mangsa, hijriah, dan Gregorian. Dengan ke-tetapan tersebut, diharapkan rakyat tidak bi-ngung dan sekaligus mengetahui dengan jelas ka-pan mulai dan berakhirnya suatu musim, dan apa yang harus dilakukan dalam kegiatan per-tanianny (Wisnubroto, 1999).

Seluk beluk pranata mangsa tak kalah rumit dengan penanggalan Mesir kuno, Cina, Maya, dan Burma, terdapat pertalian mengagumkan an-tara aspek kosmografi dan bioklimatologi yang mendasari kehidupan masyarakat tani (Dald-joeni, 1983). Pranata mangsa tersebut dilukiskan dengan berbagai lambang dan watak mangsa yang mencerminkan keselarasan antara manusia, kos-mos, dan realitas (Kepu-stakaan Populer Grame-dia dan Bentara Budaya Yogyakarta, 2011).

Pranata mangsa menggunakan tandatan-da alam sebagai petunjuk waktu tanam padi di sawah, antara lain yaitu dengan memperhatikan perilaku tanaman dan hewan, juga dengan perge-rakan rasi-rasi bintang. Gerak bumi berevolusi mengelilingi matahari mengakibatkan terjadinya perubahan musim yang berbeda, dan terlihatnya rasi bintang yang berbeda pula. Secara fisik peru-bahan musim di bumi dengan kenampakan rasi bintang tidak ada kaitannya, karena jarak yang begitu jauh antara bintang dan bumi. Namun kenampakan posisinya yang relatif selalu tetap pada setiap mangsa, maka bintang-bintang terte-ntu dimanfaatkan sebagai petunjuk musim. Dal-am banyak pustaka tentang pranata mangsa, dituliskan bintang-bintang petunjuk tersebut dengan nama-nama tradisional, misalnya Sapi Gumarang, Tagih, Lumbung, Jaran Dawuk, Banyak Angrem, Gotong Mayit, Bima Sakti, Wulanjar Ngirim, Wuluh, Waluku, Tagih, Guru Tani, Gubuk Pen-ceng, Klopo Doyong, Sangkal Putung, dan banyak lagi, namun tidak dijelaskan posisi ke-nampakan dan nama rasi bintang secara inte-rnasional (Sobirin, 2011).

Saat ini generasi muda pada umumnya dan khususnya para petani, boleh dikatakan tidak lagi yang memahami nama-nama bintang tra-disional tersebut, apa lagi posisi kenam-pa-kannya di langit. Ada upaya mencari nama bin-tang tradisional pada daftar rasi bintang Inter-national Astronomical Union (IAU), namun pada banyak pustaka sering beda interpretasi. Beberapa nama rasi bintang tradisional sudah dipahami, misalnya Waluku adalah Orion, Wuluh adalah Pleiades, Bima Sakti atau Tagih adalah Milky Way, Gotong Mayit adalah Scorpius, Klopo Doyong adalah Scorpius, Gubuk Penceng adalah Crux, Lumbung adalah Crux, Sangkal Putung adalah Scorpius (Sobirin, 2011). Dalam tulisan ini dijelaskan posisi rasi-rasi bintang menurut peta langit malam untuk daerah sekitar khatulistiwa, bila disebandingkan dengan pranatamangsa. Bintang-bintang yang dituliskan adalah bintangbintang utama petunjuk musim yang sering disebut-sebut dalam pranata mangsa, yaitu rasi bin-tang Scorpius, Centaurus, dan Crux sebagai bi-ntang petunjuk musim kemarau, sedangkan rasi bintang Orion, Pleiades, dan Taurus sebagai bi-ntang petunjuk musim hujan. Juga akan dit- 
unjukkan galaksi Milky Way yang bisa terlihat baik pada musim kemarau maupun musim hujan, terutama bila langitnya sedang cer-ah (Sobirin, 2011).

Beberapa teori yang menjadi penyebab pudarnya pemahaman terhadap pranata mangsa antara lain yaitu perubahan lingkungan karena pertambahan penduduk dan alih fungsi lahan, pe-rgeseran semu peredaran matahari, anomali iklim, dan modernisasi kehidupan.

\section{HASIL KAJIAN DAN PEMBAHASAN}

Pembahasan terhadap kebenaran pranata mangsa dan temuan-temuan empirik di lapangan yang dapat dikaitkan dengan teori-teori musim dan lingkungan terutama di Pulau Jawa dijelaskan dalam sub bab di bawah ini.

\section{Urutan Pranata Mangsa}

Dalam satu tahun pranata mangsa dibagi menjadi 12 mangsa atau musim yang berurutan sebagai pedoman andalan pertanian masa lalu. dikaitkan dengan sifat musim, perilaku tumbuhan dan hewan, kegiatan pertanian, serta posisi rasi bintang petunjuk musim diuraikan sebagai berikut (Indrowuryanto, 1999, Wisnubroto, 1999, dan Sobirin, 2011):

\section{Mangsa kasa}

Umurnya 41 hari, dari 22 Juni sampai 1 Agustus, musim kemarau. Tafsir mangsanya sotya murca ing embanan, permata permata terle-pas dari cincin pengikatnya. Sifat mangsanya udan rasa mulya, yaitu apabila pada mangsa ini ada hujan turun, maka akan memberikan kesegaran dan kesejukan. Perilaku tumbuhan berupa daun-daun berguguran dan pohon-pohon meranggas. Tanaman yang berbunga antara lain jambu, dur-ian, manggis, nangka, rambutan, srikaya, cerme, dan kedondong. Perilaku hewan antara lain telur jangkrik, gangsir, dan belalang menetas. Ikan di sungai bersembunyi, sedangkan kerbau, lembu, kuda kelihatan letih dan malas bekerja. Petani membakar sisa-sisa batang padi yang tertinggal di sawah sewaktu panen. Kemudian tanah sawah dikerjakan lagi untuk ditanami palawija seperti kacang, jagung, semangka, blewah, ubi, dam padi gadu. Pada tanah yang kering biasanya dibiarka bera. Pada mangsa Kasa, di belahan langit selata-n, pada tanggal 22 Juli, pukul 00.00 tengah malam, terlihat rasi Scorpius di barat, dan terlihat pula galaksi Milky Way memanjang dari utara ke sela-tan memotong "ekor" rasi Scorpius. Di belahan langit utara, pada tanggal dan jam yang sama, ter-lihat galaksi Milky Way memanjang dari puncak langit ke tenggara.

\section{Mangsa karo}

Umurnya 23 hari, dari 2 Agustus sampai 24 Agustus, musim kemarau. Tafsir mangsanya adalah bantala rengka, tanah retak-retak, berbongkah atau nela, karena pada mangsa ini mangsa paceklik, kurang atau tidak ada air. Sifat mangsanya gong pecah sajroning simpenan. Peri-laku tumbuhan antara lain benih palawija yang ditanam mulai tumbuh. Pohon jambu, durian, mangga gadung, nangka, rambutan mulai berbu-nga. Pohon randu bersemi, sementara pisang, je-ruk, dan sawo kecik berbuah. Perilaku hewan an-tara lain telur hewan melata, seperti ular, mulai menetas. Petani mulai resah, karena alam kering dan panas, dan mulai berusaha mencari air, baik lewat sumur, belik, atau sungai untuk mengairi tanaman palawija yang memerlukan air untuk pertumbuhannya. Pada mangsa karo, di belahan langit selatan, pada tanggal 2 Agustus, pukul 00.00 tengah malam, masih terlihat rasi Scorpius di barat, dan masih terlihat pula galaksi Milky Way memanjang dari utara ke selatan mermotong "ekor" rasi Scorpius. Di belahan langit utara, pada tanggal dan jam yang sama, terlihat galaksi Milky Way memanjang dari barat laut ke tenggara.

\section{Mangsa katiga}

Umurnya 24 hari, dari 25 Agustus sampai 17 September, musim kemarau, mangsa paceklik memuncak. Tafsir mangsanya adalah suta manut ing bapa, maksudnya anak menurut ke bapak. Sifat mangsanya resmi. Perilaku tumbuhan antara lain bambu, gadung, temu,

Jurnal Budaya Nusantara Vol. 2 No. 1 | 252 
kunyit, uwi, gembili, gembolo mulai tumbuh. Tanaman lain yang menjalar mulai tumbuh, merambat pada lanjara-nnya. Sumur-sumur mengering dan angin berde-bu. Tanah tidak dapat ditanami karena cuaca yang panas dan air yang sangat minim. Petani melaku-kan penyiraman tanaman dengan air sungai, belik, atau sumur yang masih ada airnya. Sebagian tana-man palawija sudah mulai bisa dipanen. Pada mangsa katiga, di belahan langit selatan, pada ta-nggal 25 Agustus, pukul 00.00, terlihat rasi Scor-pius mulai terbenam di barat, hanya terlihat eko-rnya saja, dan terlihat pula galaksi Milky Way me-manjang dari utara ke selatan, memotong "ekor" rasi Scorpius. Di belahan langit utara, pada tang-gal dan jam yang sama, mulai terbit rasi bintang Pleiades di timur, dan terlihat pula galaksi Milky Way memanjang dari barat laut ke tenggara.

\section{Mangsa kapat}

Umurnya 25 hari, dari 18 September sam-pai 12 Oktober, musim pancaroba, peralihan dari kemarau ke musim hujan, disebut dengan istilah labuh. Tafsir mangsanya adalah waspa kumem-beng jroning kalbu, yang diartikan mata air yang tidak keluar. Perilaku tumbuhan antara lain pohon kepel dan asam berbunga, sedangkan ta-naman duwet, durian, randu, dan nangka berbu-ah. Perilaku hewan antara lain burung pipit dan manyar mulai membuat sarang untuk bertelur. Binatang berkaki empat mulai kawin, ikan mulai keluar dari persembunyiannya. Petani masih ha-rus menunda kegembiraan, dan harus menunggu sampai kekeringan benar-benar berlalu. Sawahsawah belum dapat ditanami padi, sehingga petani menyiapkannya untuk penyemaian padi gaga. Pada mangsa kapat, di belahan langit selatan, pada tanggal 18 September, pukul 00.00, tidak terlihat lagi rasi Scorpius karena telah terbenam di kaki langit, sedangkan galaksi Milky Way nampak di barat seperti awan tipis. Di belahan langit utara, pada tanggal dan jam yang sama, terlihat rasi bi-ntang Pleiades di dekat "tanduk" rasi Taurus, dan terlihat rasi bintang Orion mulai terbit di ufuk ti-mur. Selain itu terlihat galaksi Milky Way mema-njang dari barat ke timur.

\section{Mangsa kalima}

Umurnya 27 hari, mulai 13 Oktober sampai 8 November, musim pancaroba, peralihan dari kemarau ke musim hujan, disebut den-gan istilah labuh. Tafsir mangsanya adalah pan-curan emas sumawur ing jagat, artinya hujan per-tama yang turun ke bumi merupakan karunia ya-ng sangat berharga. Perilaku tumbuhan antara la-in pohon asam berdaun muda (sinom), gadung, kunyit dan temu berdaun banyak. Pohon yang berbuah antara lain duwet, mangga, durian, cempedak, dan cerme. Perilaku hewan antara lain binatang melata, ular dan ulat, mulai keluar dari sarang. Lalat berkembang dan bertebaran. Petani mulai bersukacita atas kesegaran air hujan yang turun dari langit, layaknya emas yang jatuh ke bumi, dan mulai mengolah sawah, memperbaiki pematang (galengan), serta merencanakan peng-aturan pembagian air. Sementara itu padi gaga mulai disebar. Pada mangsa kalima, di belahan langit Selatan, pada tanggal 13 Oktober, pukul 00.00, terlihat rasi Orion di timur. Di belahan langit utara, pada tanggal dan jam yang sama, terlihat rasi bintang Pleiades di dekat "tanduk" rasi Taurus, dan rasi Orion di timur. Selain itu terlihat galaksi Milky Way memanjang dari barat ke timur.

\section{Mangsa kanem}

Umurnya 43 hari, mulai 9 November sampai 21 Desember, akhir musim pancaroba, memasuki awal musim hujan, kadang-kadang disertai petir hingga sering terjadi tanah longsor. Tafsir mangsanya adalah rasa mulya kasucen, artinya perasaan bahagia yang sebenar-benarnya. Perilaku tumbuhan mangga, durian, dan rambutan mulai masak. Perilaku hewan antara lain lipas atau kecoa dan kumbang air ber-kembang dalam parit. Burung air seperti blekok dan kuntul, mulai terlihat mencari mangsa di lahan yang berair. Petani dipenuhi rasa syukur karena menerima limpahan berkah dari alam, dan 
mulai memba-jak mengerjakan sawah untuk ditanami padi. Ben-ih padi yang berupa gabah mulai disemai. Pada mangsa kanem, di belahan langit selatan, pada ta-nggal 9 November, pukul 00.00, terlihat rasi Ori-on di Timur, dan terlihat pula galaksi Milky Way di sudut langit timur, memanjang dari timur laut ke tenggara. Di belahan langit utara, pada tanggal dan jam yang sama, terlihat rasi bintang Pleiades di dekat "tanduk" rasi Taurus, dan terlihat rasi bintang Orion agak di puncak langit. Selain itu terlihat galaksi Milky Way memanjang dari timur laut ke barat daya.

\section{Mangsa kapitu}

Umurnya 43 hari, mulai 22 Desember sa-mpai 2 Februari, musim penghujan, atau rend-heng, dengan curah hujannya yang deras sekali. Tafsir mangsanya adalah wisa kentar ing maruta, artinya racun terbang tertiup angin. Sifat mang-sanya adalah guci pecah ing segara, artinya hujan terus menerus dengan curah hujan yang tinggi, sumber-sumber air menjadi besar, angin kencang, dan sungai- sungai meluap. Inilah mangsa datang-nya penyakit dan banjir. Ketenteraman petani sejenak terganggu. Dalam mangsa ini, alam alam kelihatannya kurang bersahabat, namun sesungg-uhnya menyimpan berkah panen. Perilaku tum-buhan antara lain durian, kepundung, salak, nan-gka belanda, kelengkeng, dan gandaria masih ber-buah. Perilaku hewan antara lain burung-burung sulit mencari makan. Pada mangsa ini petani mulai menanam bibit padi (tandur), juga mem-perbaiki pematang yang rusak akibat hujan yang deras. Pada mangsa kapitu, di belahan langit sela-tan, pada tanggal 22 Desember, pukul 00.00, terli-hat rasi Orion di puncak langit, terlihat pula gal-aksi Milky Way memanjang dari utara ke selatan di kiri rasi Orion. Di belahan langit utara, pada tanggal dan jam yang sama, terlihat rasi bintang Ple-iades di dekat "tanduk" rasi Taurus mulai con-dong ke barat, dan terlihat rasi bintang Orion di puncak langit. Selain itu terlihat galaksi Milky Way memanjang dari utara ke selatan di sebelah kanan rasi Orion.

\section{Mangsa kawolu}

Umurnya 27 hari, mulai 3 Februari sampai 28 Februari (berlaku untuk tahun Wastu), huj-an mulai berkurang dan sering terdengar guntur dan kilat menyambar. Tafsir mangsanya adalah anjrah jroning kayun, artinya tersebar merata dalam hati, suka cita ada di depan mata. Sifat ma-ngsanya cantika, hujan mulai jarang, tetapi bunyi guntur sering terdengar. Perilaku tumbuhan an-tara lain nampak pohon- pohon yang mulai ber-bunga antara lain sawo manila, kepel, dan gayam, sedangkan yang berbuah antara lain wuni, kepun-dung, dan alpuket. Perilaku binatang antara lain kucing kawin, tonggeret atau garengpung ber-kembang biak, kunang-kunang bertebaran di saw-ah, uret juga banyak muncul. Petani melakukan kegiatan pemeliharaan seperti mematun, me-ndangir, dan merabuk. Tanaman padi sudah mu-lai tinggi dan ada yang mulai berbunga. Seme-ntara di ladang petani panen jagung. Pada mangsa kawolu, di belahan langit selatan, pada tanggal 3 Februari, pukul 00.00, terlihat rasi bintang Crux di timur, rasi bnitang Orion di barat, dan terlihat pula galaksi Milky Way memanjang dari barat laut ke selatan. Di belahan langit utara, pada tanggal dan jam yang sama, terlihat rasi bintang Pleiades di dekat "tanduk" rasi Taurus, dan terlihat rasi bintang Orion mulai mulai condong ke barat. Se-lain itu terlihat galaksi Milky Way di sebelah ka-nan rasi Orion memanjang dari utara ke selatan.

\section{Mangsa kasanga}

Umurnya 25 hari, mulai 1 Maret sampai 25 Maret, berakhirnya musim hujan. Tafsir man-gsanya adalah wedaring wacana mulya, artinya tersiarnya kabar berita. Perilaku tumbuhan antara lain pohon-pohon yang masih berbunga yaitu kawista, durian, dan sawo kecik. Pohonpohon yang berbuah antara lain alpuket, duku, kepu-ndung, dan wuni. Sementara padi mulai berisi atau berbulir, bahkan ada yang sudah menguning. Perilaku hewan antara lain tonggeret mulai banyak di pepohonan, garengpung ngereng, jang-krik ngerik, dan kucing mulai bun-ting. Petani mulai 
mengerjakan tegalannya, dan di sawah mu-lai membuat orang-orangan yang diikat tali untuk mengusir burung. Pada mangsa kasanga, di belahan langit selatan, pada tanggal 1 Maret, pukul 00.00, terlihat rasi bintang Crux di timur, rasi bintang Scorpius nampak mulai terbit di kaki lan-git timur. Terlihat pula rasi Centaurus di sebelah kanan bawah rasi bintang Crux. Sedangkan rasi Orion mulai terbenam di barat. Selain itu terlihat pula galaksi Milky Way memanjang dari barat laut ke barat daya memotong rasi Crux. Di belahan langit utara, pada tanggal dan jam yang sama, terlihat rasi Orion di sudut langit barat, rasi bintang Pleiades dan rasi Taurus tidak terlihat lagi karena sudah terbenam di kaki langit barat. Selain itu terlihat galaksi Milky Way di sebelah kanan rasi Orion seperti awan memanjang dari utara ke selatan.

\section{Mangsa kadasa}

Umurnya 24 hari, mulai 26 Maret sampai 18 April, musim pancaroba atau peralihan dari musim hujan ke musim kemarau, disebut mareng. Tafsir mangsanya adalah gedong mineb jro-ning kalbu, artinya buah hati dalam hati. Perilaku tumbuhan antara lain padi di sawah menguning, padi gogo di tegalan siap dipanen, pohon-pohon yang berbuah antara lain alpuket, jeruk nipis, duku, dan salak. Perilaku hewan antara lain sapi dan kerbau bunting, burungburung berkicau dan membuat sarang, mulai bertelur. Petani panen padi gaga di tegalan, dan di sawah sibuk meng-halau burung pipit dan burung pemakan padi lainnya yang berusaha memakan bulir-bulir padi. Walaupun demikian, terasa sedikit meresahkan karena tak lama lagi musim kemarau akan datang, dan nampak orang mudah lesu dan pusing. Pada mangsa kadasa, di belahan langit selatan, pada ta-nggal 26 Maret, pukul 00.00, terlihat rasi bintang Crux di tengah langit selatan, rasi Scorpius di ti-mur, dan rasi Centaurus bersinar terang di dekat rasi Crux. Selain itu terlihat pula galaksi Milky Way memanjang dari timur ke barat memotong ekor rasi Scorpius dan rasi Crux. Di belahan langit utara, pada tanggal dan jam yang sama, terlihat galaksi Milky Way seperti awan tipis di sudut kaki langit barat.

255 | Jurnal Budaya Nusantara Vol. 2 No. 1

\section{Mangsa dhesta}

Umurnya 23 hari, mulai 19 April sampai 11 Mei, musim pancaroba atau peralihan dari musim hujan ke musim kemarau, disebut mareng. Udaranya panas di siang hari. Alam menunjukkan daya ciptanya menjelang musim kemarau makin dekat. Tafsir mangsanya adalah sotya sinorowedi, artinya permata hati, penuh kasih sayang. Perilaku tumbuhan antara lain umbi-umbian dan tanaman padi siap dipanen. Perilaku hewan antara lain telur burung menetas, induk burung pemakan biji-bijian, seperti pipit, punai, manyar memberi makan anaknya (ngloloh). Petani sibuk menuai padi di sawah dan melakukan panen umbi-umbian di tegalan. Pada mangsa dhesta, di belahan langit selatan, pada tanggal 19 April, pukul 00.00, terlihat rasi bintang Crux di tengah langit selatan, rasi Scorpius di timur, dan rasi Centaurus bersinar terang di dekat rasi Crux. Selain itu terlihat pula galaksi Milky Way memanjang dari timur ke barat memotong ekor rasi Scorpius dan rasi Crux. Di belahan langit utara, pada tanggal dan jam yang sama, terlihat galaksi Milky Way seperti awan tipis di sudut kaki langit timur.

\section{Mangsa shada}

Umurnya 41 hari, mulai 12 Mei sampai 21 Juni, akhir mareng masuk ke awal kemarau, tidak ada hujan lagi, disebut juga mangsa bedhidhing, udara terasa dingin di pagi hari. Tafsir mangsanya adalah tirta sah saking sasana, artinya air hilang dari tempatnya. Sifat mangsanya adalah rontoging taru lata, artinya daun-daun layu karena terik panas matahari di siang hari. Air mulai berkurang di sumur, hingga banyak orang mulai mencari air dari tempat lain (ngangsu). Perilaku tumbuhan antara lain pohon yang berbuah jeruk keprok, nanas, alpuket, dan kesemek. Perilaku hewan antara lain rajakaya (kerbau dan sapi) dikandang-kan untuk diistirahatkan. Petani selesai memanen padi, kemudian melakukan penjemuran gabah untuk selanjutnya disimpan dalam lumbung, kemudian membakar sisa-sisa jerami di sawah, dan melakukan persiapan mengerjakan tanah untuk ditanami palawija. Pada mangsa dhesta, di 
belahan langit selatan, pada tanggal 12 Mei, pukul 00.00, terlihat rasi bintang Crux mulai condong ke barat, rasi Scorpius di tengah langit, dan rasi Centaurus masih bersinar terang di dekat rasi Crux. Selain itu terlihat pula galaksi Milky Way memanjang dari timur laut ke barat daya memo-tong ekor rasi Scorpius dan rasi Crux. Di belahan langit utara, pada tanggal dan jam yang sama, ter-lihat galaksi Milky Way di timur memanjang dari utara ke selatan.

Berdasar uraian masing-masing mangsa yang mempunyai pola akan berulang setiap tahunnya dapat dikatakan bahwa pada zaman itu suasana alam Pulau Jawa saat itu relatif stabil belum dipengaruhi oleh anomali iklim, baik oleh faktor regional maupun faktor lokal.

\section{Bencana Telah Ada Sejak Zaman Dulu}

Daur pranata mangsa dibagi ke dalam 4 mangsa besar atau musim besar, yaitu pertama mangsa katiga atau musim kemarau, berumur 88 hari, kedua mangsalabuh atau pancaroba menjelang musim hujan berumur 95 hari, ketiga mangsarendheng atau musim hujan berumur 94 hari, keempat mangsamareng atau pancaroba menjelang musim kemarau berumur 88 hari (Indrowuryanto, 1999, dan Wisnubroto, 1999). Berdasar daur pranata mangsa, ancaman terjadinya bencana lingkungan berupa banjir dan kekeringan telah dapat diprediksi jauh sebelumnya.

Bencana banjir, terjadi pada mangsa rend-heng, karena curah hujan menjadi semakin tinggi. Mangsa ini dibagi lagi kedalam dua mangsa yang lebih rinci, yaitu mangsa kapitu, dan mangsa kawolu. Mangsa kapitu, umurnya 43 hari, mulai 22 Desember sampai 2 Februari, kondisi alamnya sedang musim hujan dengan curah hujannya yang deras sekali. Sumbersumber air menjadi besar, angin kencang, dan sungai-sungai meluap. Mang-sa kawolu, umurnya 27 hari, mulai 3 Februari sampai 28 Februari (berlaku untuk tahun Was-tu), hujan mulai berkurang dan sering terdengar guntur dan kilat menyambar. Sebelum mangsa rendheng datang, musim hujan telah mulai dira-sakan pada waktu mangsa labuh, yang terbagi dalam dua mangsa yaitu mangsa kalima dan mangsa kanem. Mangsa kalima umurnya 27 hari, mulai 13 Oktober sampai 8 November, musim pancaroba, peralihan dari kemarau ke musim hujan, ditandai dengan hujan pertama yang turun ke bumi. Sedangkan mangsa kanem umurnya 43 hari, mulai 9 November sampai 21 Desember, akhir musim pancaroba, memasuki awal musim hujan, kadang-kadang disertai petir hingga sering terjadi tanah longsor.

Bencana kekeringan, terjadi pada musim kemarau karena air yang minim dan tanah yang kering. Mangsa ini dibagi lagi kedalam tiga mangsa yang lebih rinci, yaitu mangsa kasa, mangsa karo, dan mangsa katiga. Mangsa kasa, umurnya 41 hari, dari 22 Juni sampai 1 Agustus, kondisi alamnya antara lain tanah mengering karena air mulai berkurang, daundaun berguguran dan pohon meranggas. Mangsa karo, umurnya 23 hari, dari 2 Agustus sampai 24 Ag-ustus, kondisi alamnya berupa tanah retakretak karena pada mangsa ini kurang atau tidak ada air. Petani mulai berusaha mencari air dari tempat lain. Bahkan mangsa karo ini disebut juga sebagai mangsa paceklik, yaitu sulit air dan pangan. Ma-ngsa katiga yang berumur 24 hari, dari 25 Agustus sampai 17 September, kondisi alamnya ditandai dengan sumur-sumur yang mengering dan angin berdebu, dan puncaknya mangsa paceklik. Tanah tidak dapat ditanami karena kering dan retak-retak, serta air yang sangat minim. Pada mangsa ini petani melakukan penyiraman tanaman den-gan air sungai, belik, atau sumur yang masih ada airnya. Sebelum kemarau datang, kekeringan te-lah mulai dirasakan, yaitu pada mangsa sadha, yang berumur 41 hari, mulai 12 Mei sampai 21 Juni. Kondisi alamnya tidak ada hujan lagi, air hilang dari tempatnya. Daun-daun layu karena terik panas matahari di siang hari. Air mulai berkurang di sumur, hingga banyak orang mulai me-ncari air dari tempat lain (ngangsu). Setelah mangsa ketiga berakhir, kekeringan juga masih dirasakan, yaitu pada mangsa kapat yang beru- 
murnya 25 hari, dari 18 September sampai 12 Oktober. Pada mangsa ini mata air dan sumber air lain masih minim, dan petani masih harus me-nunda kegembiraan, serta harus menunggu sam-pai kekeringan benar-benar berlalu. Sawahsawah belum dapat ditanami padi, sehingga petani men-yiapkannya untuk penyemaian padi gaga.

Pada zaman dulu, saat mengalami peristiwa kekeringan, penduduk desa atau kota biasanya berkumpul untuk menonton wayang yang menceritakan kisah dalam pawukon Raja Watu Gunung dan permaisurinya yaitu Dewi Sinta. $\mathrm{Pa}-$ da peristiwa ini, dua batang tebu yang berwarna gelap, dua kelapa muda dan tua, dua ikat padi de-ngan warna berbeda, dua ikat bunga pinang, selembar kain putih, minyak wangi, dua ekor unggas dan dua ekor bebek, diletakkan di sebelah dalang selama pertunjukan dan kemudian dian-ggap sebagai miliknya (Raffles, 1817).

Berdasar uraian tersebut di atas, ternyata memang banjir dan kekeringan telah ada sejak da-hulu. Pada zaman tersebut, kemungkinan terja-dinya bencana lingkungan terkait air tersebut telah dapat diprediksi jauh sebelumnya, sesuai dengan mangsa-mangsa tertentu yang tertulis dalam pranata mangsa.

\section{Pudarnya Sebuah Kearifan}

Pada tahun 1999, telah dilakukan studi jajak pendapat berdasar kuesioner untuk mengetahui keberadaan pranata mangsa di tengah masyarakat (Wisnubroto, 1999). Dari 451 respo-nden di Kabupaten Boyolali, Jawa Tengah, dapat diketahui bahwa masih cukup banyak responden yang mengetahui pranata mangsa, yaitu jum-lahnya mencakup 65,6\% dari seluruh responden. Berdasar tingkat pendidikan responden, diketa-hui bahwa yang paling banyak mengetahui pran-ata mangsa adalah yang berpendidikan sekolah dasar yaitu sebanyak $73,1 \%$.

Angka memberikan petunjuk bahwa mas-yarakat yang berpendidikan relatif tinggi rupa-rupanya menganggap bahwa sesuatu yang

257 | Jurnal Budaya Nusantara Vol. 2 No. 1 bersifat tradisional adalah kurang bermanfaat. Berdasar umur responden, dapat diketahui yang banyak mengetahui pranata mangsa adalah yang berumur 61-80 tahun, yaitu sebanyak 69,1\%. Hal ini dapat dijadikan petunjuk bahwa kelompok masyarakat yang relatif lebih tua adalah yang lebih banyak mengetahui pranata mangsa. Berdasar sumber informasi dari responden yang mengetahui pra-nata mangsa, sebanyak 93,9\% mendapatkan in-formasi dari orang tua, dari guru $4,1 \%$, dari mem-baca $3,4 \%$, dan dari sumber lain 1,4\%. Dari ang-ka-angka tersebut, rupa-rupanya pengenalan pr-anata mangsa diperoleh secara lisan dari generasi ke generasi, yaitu sumber utamanya dari orang tua kepada anak cucunya. Di samping itu, ada juga kemungkinan sebab lain, yaitu pada tahun 1960-an pranata mangsa masih diajarkan di tingkat pen-didikan sekolah rakyat, sekarang namanya seko-lah dasar, di daerah Surakarta dan sekitarnya. Pa-da waktu sekarang, pengetahuan, pranata mangsa ini secara khusus tidak diajarkan lagi. Inilah yang mungkin menyebabkan terlihat peranan guru sangat kecil (Wisnubroto, 1999).

Orang tua zaman dulu mengatakan jangan terjebak bulan berdasar kalender Grego-rian Masehi. Kalau belum masuk mangsa kanem, belum saatnya masuk musim hujan. Tapi sekar-ang ternyata susah ditebak, kapan musim hujan akan datang. Mangsa kanem merupakan musim ketika para petani mulai menanam. Konon, jika menanam pada musim ini akan selamat hingga musim panen. Akan tetapi, perubahan lingku-ngan dan musim yang ekstrim telah mengakib-atkan perkiraan munculnya musim hujan sering meleset, walaupun rasi bintang Waluku atau Ori-on, yang menjadi patokan penentuan musim hu-jan, telah terlihat di langit (KOMPAS.com, 2009).

Kemajuan teknologi yang diterapkan di Pulau Jawa semenjak 1970-an, berupa paket intensifikasi pertanian seperti penggunaan pupuk kimia, jenis padi berumur genjah yang dapat dipanen pada umur 120 hari atau kurang, padal sebelumnya memerlukan waktu hingga 180 hari, telah menyebabkan pranata mangsa kurang mendapat perhatian. Demikian pula meluasnya jarin- 
gan irigasi melalui bendungan atau bendung yang telah banyak dibangun, dan terutama berkem-bang pesatnya teknik prakiraan cuaca telah me-nyebabkan pranata mangsa telah menjadi usang karena kehilangan banyak relevansi. Isu peru-bahan iklim global yang semakin menguat sem-enjak 1990-an juga membuat pranata mangsa perlu ditinjau kembali karena dianggap "tidak lagi dapat dibaca" (Wikipedia, 2015).

Setelah hampir dua dekade sejak jajak pendapat pada tahun 1999, maka dilakukan kem-bali jajak pendapat berdasar wawancara langsung terhadap 10 responden yang terkait dengan pran-ata mangsa dan pertanian di Jawa Barat, Jawa Te-ngah, dan Jawa Timur pada tahun 2016 (Adhitya dan Sobirin, 2016). Berdasar 10 orang responden lapangan tersebut, terdapat tiga kelompok berb-eda dalam menanggapi tentang keberadaan pra-nata mangsa. Empat orang paham tentang pra-nata mangsa, tetapi tidak memanfaatkannya dal-am kegiatan pertanian. Satu orang pernah mendengar tentang keberadaan pranata mangsa, tetapi tidak bisa menjelaskan rinciannya. Lima orang lainnya sama sekali tidak memahami tentang ke-beradaan pranata mangsa.

\section{Pranata Mangsa dan Perubahan Lingkungan}

Suasana Pulau Jawa pada pertengahan abad 19, pernah ditulis oleh Thomas Stamford Raffles ketika menjabat sebagai Letnan Gubernur Jawa pada tahun 1811, dengan judul bukunya The History of Java (Raffles, 1817). Dikatakan bahwa Pulau Jawa sangat bagus untuk pertanian, karena tanahnya sangat subur. Para petani tidak hanya menanam sebatas untuk memenuhi kebutuhan dasarnya, tetapi juga untuk memenuhi kebutuhan lainnya, seperti membeli barang-barang kebu-tuhan yang sedikit mewah. Penduduk Pulau Jawa adalah bangsa petani, dan akhirnya membentuk struktur masyarakat yang sah. Petani mendapat uang dari tanamannya, prajurit dari upahnya, pegawai dari gajinya, para ulama dari sumbangan (zakat), dan permerintah dari hasil pajak. Kek-ayaan suatu desa atau satu propinsi tergantung dari luas dan kesuburan tanahnya, sistem pen-gairannya, serta jumlah kerbau yang dimiliki. Ber-as merupakan makanan utama penduduk Jawa, seperti juga di India, sehingga tanaman lain dianggap kurang penting dibanding padi. Pulau-pulau Sumatera, Malaka, Borneo, Celebes, Mal-uku, dan pulaupulau kecil lainnya, seringkali ter-gantung pada hasil panen dari Jawa. Pemerintah Kolonial Belanda sendiri setiap tahunnya mem-bawa sekitar 6-8 ribu ton ke Koromandel, Cey-lon, Tanjung, dan wilayah koloni mereka lainnya. Bahkan dengan harga beras yang murah, Pemerintah Kolonial Belanda tiap tahunnya mendapat keuntungan sebesar 4 juta rupee, atau setengah juta sterling dari hasil panen. Berdasarkan buku The History of Java tersebut, diketahui bahwa pa-da sekitar awal abad 19 Pulau Jawa merupakan pulau yang subur dan makmur. Walaupun saat itu pranata mangsa belum ditetapkan menjadi kalen-der resmi pertanian, namun para petani telah me-mahami perihal siklus musim dan memanfaatkan-nya sebagai pedoman pertanian.

Namun kondisi Pulau Jawa saat ini telah sangat berbeda dengan kondisi pada abad 19, an-tara lain yaitu perubahan lingkungan karena per-tambahan penduduk dan alih fungsi lahan, perg-eseran semu peredaran matahari, anomali iklim, dan modernisasi kehidupan.

Pulau Jawa adalah sebuah pulau di Indonesia dengan luasnya $128.297 \mathrm{~km}^{2}$, merupakan pulau terluas ke-13 di dunia. Pada tahun 2018 jumlah penduduk Pulau Jawa 149,6 juta jiwa, merupakan pulau dengan penduduk terbanyak di dunia dan merupakan salah satu tempat terpadat di dunia. Luas Pulau Jawa kurang lebih hanya $7 \%$ dari total luas Indonesia, dengan ketersediaan air tawarnya hanya $4 \%$ dari total ketersediaan air Indonesia. Pada tahun 1815, ketika penduduk Pulau Jawa masih berjumlah 4.600.000 jiwa, digambarkan Pulau Jawa subur makmur, bah-kan mampu mengekspor beras ke pulau-pulau lain. Pada dekade 1960Jurnal Budaya Nusantara Vol. 2 No. 1 | 258 
an, ketika jumlah pen-duduknya sekitar 63.000.000 kepadatan pendu-duk di Pulau Jawa telah melintasi titik keseim-bangan antara persediaan dan kebutuhan mini-mum lahan pertanian yang dibutuhkan oleh kelu-arga petani (Simon, 2001). Pada tahun 2015 lebih dari 50\% penduduk Indonesia tinggal di Pulau Jawa, sehingga potensi airnya yang kurang lebih 1.500 m3/kapita/tahun tidak mencukupi. Pulau Jawa dapat dikatakan dalam kondisi water stress dalam penyediaan air, karena berada di bawah angka normal yaitu $2.000 \mathrm{~m} 3$ per kapita/tahun (Pusat Komunikasi Publik, 2012). Pada tahun 19-50, Pulau Jawa memiliki hutan dengan luas 5.070.000 hektar, dan sawah sekitar 6.150 .000 hektar, yaitu sawah beririgasi dan tadah hujan (Forest Watch Indonesia dan Global Forest Watch, 2001). Jauh sebelum tahun 2009, hutan al-am Pulau Jawa telah mulai menyusut sebagai dampak era pembangunan infrastruktur yang di-mulai tahun 1970. Pada tahun 2013 tutupan hu-tan alamnya tinggal 675.000 hektar (Forest Watch Indonesia, 2014), berarti sejak tahun 1950 hingga tahun 2013 luas hutannya telah menyusut hingga 86,69\%. Pada tahun 1950, Pulau Jawa memiliki sawah 6.150.000 hektar, sedangkan pada tahun 2013 sawahnya tinggal 3.231.377 hektar, berarti sejak tahun 1950 hingga tahun 2013 luas sawahnya telah jauh sangat menyusut hingga 47,46\% (Pusat Data dan Sistem Informasi Pertanian, 2014). Dampak dari keadaan ling-kungan ini, maka dari tahun 2009 hingga 2013, Pulau Jawa telah mengalami bencana terkait air berupa kejadian tanah longsor 1.150 kali, kejadian banjir 1.467 kali, kejadian kekeringan 299 kali. Keadaan seperti itulah yang patut diduga sebagai penyebab pranata mangsa tidak akurat lagi.

Bumi berevolusi mengelilingi matahari mengakibatkan perbedaan lama siang dan malam di belahan bumi utara dan selatan, mengakibatkan terjadinya empat musim di belahan bumi utara dan selatan, terjadinya gerak semu matahari, terli-hatnya rasi bintang yang berbeda.

Semenjak ditetapkannya pranata mangsa menjadi kalender resmi pertanian oleh Sri 259 | Jurnal Budaya Nusantara Vol. 2 No. 1
Paduka Susuhunan Paku Buwono VII dari Kerajaan Su-rakarta pada tanggal 22 Juni 1855, maka kini umur kalender Pranata mangsa ini ini telah lebih dari satu setengah abad. Pranata mangsa telah me-ngalami penyimpangan karena pranata mangsa menggunakan hitungan waktu revolusi bumi me-ngelilingi matahari dalam 365,25 hari, padahal waktu lebih rincinya adalah 365 hari, 5 jam, 48 menit, 46 detik, sehingga terdapat selisih waktu 11 menit, 14 detik dalam satu tahun, atau lebih dari puluhan hari hingga saat ini. Dengan adanya penyimpangan ini, maka pada tahun 1997, tanggal 13 Oktober sampai 9 November, yang dalam pranata mangsa masuk mangsa kalima yaitu awal musim hujan, pada kenyataannya saat itu belum merupakan awal musim hujan, bahkan masih terjadi musim kemarau yang panas (Indrowuryanto, 1999). Peristiwa ini menunjukkan bahwa kalender pranata mangsa memang sudah saatnya perlu mendapat perhatian untuk dimodifikasi.

Anomali iklim seperti kemarau yang basah dan musim hujan yang kering sebenarnya sudah sering terjadi di wilayah Indonesia. Studi yang dilakukan oleh seorang ahli meteorologi Be-landa, Braak (1920), dalam Yulihastin (2013), me-nuliskan bahwa anomali iklim pada masa itu telah mengakibatkan para petani menunggu hujan turun di musim hujan dengan sia-sia. Di waktu lain, hujan masih terus terjadi pada musim kemarau. Walaupun pada masa itu fenomena El Nino dan La Nina di Samudera Pasifik, serta Dip-ole Mode positif dan negatif di Samudera Hindia belum dikenal oleh ilmuwan, namun Braak (1920) sudah menduga kuat bahwa terjadinya anomali iklim di Indonesia berhubungan erat dengan fak-tor regional yang lebih luas. Faktor regional lain yang dapat menyebabkan anomali iklim adalah sirkulasi gelombang MJO (Madden Julian Oscillation) dengan delapan fase penjalaran. Gelombang MJO ini dapat dikenali dari pembentukan awan-awan konveksi yang berkumpul secara massif (super cloud cluster), menjalar dari pantai timur Afrika, lalu menuju timur ke Samudera Hindia, melewati Benua Maritim Indonesia, Samudera Pasifik, hingga meluruh di atas Pasifik ti- 
mur. Arak-arakan awan MJO yang menjalar seca-ra periodik tersebut juga kerap kali meningkatkan aktivitas konveksi di atas wilayah Indonesia dan menimbulkan hujan yang terus menerus (Yuli-hastin, 2013). Selain faktor-faktor regional, me-nurut studi Qian et al. (2011), dalam Yulihastin (2013) juga terdapat faktor lokal di suatu wilayah seperti topografi berupa dataran tinggi, kompo-sisi dan orientasi lautandaratan yang berbeda, sering berpengaruh membentuk perilaku iklim yang ganjil dan tampak inkonsisten. Misalnya, pa-da saat hampir seluruh wilayah mengalami dam-pak El Nino yaitu kekeringan, Jawa Barat bagian tengah dan selatan tetap memiliki curah hujan tinggi bahkan lebih tinggi dari normal. Peristiwa anomali iklim tersebut di atas, telah menyebabkan perhitungan pranata mangsa sering meleset.

Modernisasi kehidupan yang tidak berwa-wasan lingkungan yang sekarang terjadi, termasuk sebagai penyebabterhadap penyimpangan pra-nata mangsa. Saat awal dan akhir musim kema-rau, sering dilakukan modifikasi cuaca, dengan merangsang awan agar bisa menjadi hujan de-ngan menyebarkan unsurunsur garam yang bersifat higroskopis. Hujan yang terjadi, secara umum disebut hujan buatan, yang dapat menga-caukan penerapan penanggalan pranata mangsa sebagai pedoman para petani. Ekstensifikasi jari-ngan irigasi yang mengalirkan air dari waduk dan bendung ke wilayah pelosok pedesaan, sehingga daerahdaerah yang terjangkau irigasi teknis tidak akan kekurangan air di musim kemarau. Keadaan ini dimanfaatkan petani untuk memb-udidayakan tanah sawahnya sepanjang tahun. De-ngan demikian, pranata mangsa sebagai pedoman bertani tidak di-hiraukan lagi penerapannya. Kemajuan teknologi dan berbagai teknik rekayasan genetika di bidang pertanian telah berhasil mene-mukan benih-benih tanaman padi yang berkw-alitas. Berkat benih yang umurnya lebih pendek ditambah lagi dengan memanfaatkan pupuk kim-ia, maka produktivitas sawahnya akan meningkat, sehingga petani menganggap pranata mangsa te-lah usang. Penggunaan bahan bakar fosil sebagai sumber energi dapat meningkatkan konsentrasi gas-gas rumah kaca yang menghambat peman-tulan kembali sebagian udara panas ke ruang angkasa, akibatnya permukaan bumi dan atmos-fer menjadi memanas, dan mengganggu keseimbangan kehidupan di muka bumi. Demikian pula penggunaan gas penyejuk pada lemari es, gas penyaman udara pada air conditioner, dan juga melalui bahan semburan aerosol pada penyembur racun serangga secara tidak sadar menghasilkan gas klorofluorokarbon atau juga dikenali sebagai CFC, yang kemudian menguap di atmosfer mengikis lapisan ozon. Padahal, lapisan ozon berfungsi melindungi bumi dari sinar ultra ungu, dan menyerap serta membalikkan sinar ultra ungu yang berlebihan ke angkasa. Akibat dari pema-nasan dipermukaan bumi dan sinar ultra ungu ya-ng berlebihan akan memudaratkan kehidupan di bumi, yang pada giliran berikutnya dapat memicu anomali iklim, sehingga acuan pranata mangsa ti-dak cocok lagi.

\section{Pranata Mangsa di Masa Depan}

Berdasar uraian dalam paragraf-paragraf sebelumnya, sejarah zaman keemasan sampai pu-darnya pranata mangsa, dapat dibagi dalam be-berapa periode.

1) Periode pertama, sekitar tahun 1817 sepe-rti yang diceritakan oleh Raffles (1817), unsur-unsur pranata mangsa telah dima-nfaatkan oleh petani untuk kegiatan per-taniannya.

2) Periode kedua, sekitar tahun 1855, ketika pranata mangsa ditetapkan oleh Sri Paduka Susuhunan Pakubuwono VII sebagai kalender resmi pertanian, hingga sekit-ar tahun 1900, maka pranata mangsa me-njadi pedoman andalan dalam kegiatan bertani. Walaupun dalam periode ini mu-ncul banjir dan kekeringan, namun keja-diannya masih sesuai dengan yang terse-but dalam pranata mangsa (Indro-wuryanto, 1999, dan Wisnubroto, 1999).

Jurnal Budaya Nusantara Vol. 2 No. 1 | 260 
3) Periode ketiga, sekitar tahun 1920, ketika mulai diketahui adanya anomali iklim, pa-ra petani menunggu hujan turun di mu-sim hujan dengan sia-sia, seperti ditulis oleh Braak (1920), dalam Yulihastin (20-13). Periode ini rupanya terus berlang-sung hingga tahun 1960an, saat Pulau Jawa melintasi titik keseimbangan antara persediaan dan kebutuhan minimum lah-an pertanian (Simon, 2001). Pranata man-gsa telah banyak meleset dari kenyataan, namun sebagian masyarakat masih memanfaatkannya. Bahkan pada tahun 1960an konsep pranata mangsa merupakan mata pelajaran di sekolah, di daerah Surakarta dan Yogyakarta (Wisnubroto, 1999).

4) Periode keempat, sekitar tahun 1970 ketika hingga tahun 1990 ketika pembangunan infrastruktur di Pulau Jawa meningkat pesat, sehingga pranata mangsa mulai terabaikan. Bahkan sekitar tahun 1997, pranata mangsa semakin tidak akurat karena terdapat penyimpangan terhadap perhitungan peredaran semu matahari (Indrowuryanto, 1999). Hal ini terbukti dari hasil studi jajak pendapat yang dilakukan pada tahun 1999, dengan hasil bahwa masih banyak kelompok masyarakat yang paham tentang pranata mang-sa, namun sebagian besar tidak meman-faatkannya dalam kegiatan pertanian (Wi-snubroto, 1999).

5) Periode kelima, sekitar tahun 2000 hingga terakhir tahun 2016 berdasar dialog de-ngan petani dan anggota masyarakat la-innya di Jawa Barat, Jawa Tengah, dan Ja-wa Timur (Adhitya dan Sobirin, 2016), ternyata pranata mangsa hanya dipahami saja dan tidak dimanfaatkan, bahkan se-bagian tidak paham sama sekali tentang keberadaan pranata mangsa.
Memudarnya pranata mangsa agaknya diawali pada periode ketiga, ketika penduduk Pu-lau Jawa semakin meningkat. Kemudian semakin memudar dan dianggap usang pada periode kee-mpat dan kelima. Pembangunan infrastruktur di Indonesia, termasuk di Pulau Jawa, yang telah dilakukan sepanjang tahun 1970 dengan pend-ekatan tekno-ekonomi, top down dan sentralis-tik, karena didorong oleh kebutuhan yang me-ningkat pesat, sebenarnya telah cukup berhasil untuk memenuhi kebutuhan hidup masyarakat. Namun dalam jangka panjang konsep pemba-ngunan semacam ini telah menyebabkan kerus-akan lingkungan alam yang berlebihan. Ditam-bah lagi dengan terjadinya anomali iklim yang semakin meningkat, maka telah mengakibatkan perhitungan pranata mangsa menjadi banyak me-leset dan kacau, seperti yang tersebut dalam pe-riode keempat dan kelima di atas.

Pada awal abad 21, berdasar usulan banyak pihak yang berkecimpung dalam kelestarian lingkungan, muncul konsep pem-bangunan yang berbasis keberlanjutan ekologi. Paradigma ini bukanlah sekedar pembangunan seperti masa lalu, tapi termasuk mempertahankan dan melestarikan ekologi dan seluruh ke-kayaannya. Pembangunan ekonomi dilakukan sekaligus melestarikan ekosistem di sekitarnya. Keberhasilan pa-radigma ini bukan diukur dengan indikator mat-erial, tetapi pada kualitas hidup yang dicapai de-ngan menjamin kehidupan ekologis, sosial-budaya dan ekonomi secara proporsional. Gaya hidup yang dibangun tidak lagi gaya hidup yang didasarkan pada eksploitasi, produksi, dan kon-sumsi yang berlebihan, melainkan dengan konsep "simple in means, but rich in ends", bukan "ha-ving more tapi being more" (Keraf, 2010). Seb-uah harapan bahwa budaya pranata mangsa akan hidup kembali bila konsep pembangunan berba-sis keberlanjutan ekologi ini dijalankan dengan konsekwsen, yang tentunya perlu sekali dukungan yang terintegrasi berupa "political will" dari pem-erintah, "educational will" dari kalangan aka-demisi, dan "cultural will" dari masyarakat. 
Kearifan tradisional termasuk budaya pranata mangsa, adalah pengetahuan yang secara turun-temurun dimiliki oleh masyarakat dalam mengelola lingkungan hidupnya. Dengan demikian kearifan tradisional merupakan pandangan dan pengetahuan tradisional yang menjadi acuan dalam berperilaku yang telah dipraktekkan secara turun-temurun untuk memenuhi kebutuhan dan tantangan dalam kehidupan masyarakat. Kearifan tradisional berfungsi dan bermakna dalam mas-yarakat baik dalam pelestarian sumber daya alam, adat, adab dan budaya, sehingga berma-nfaat untuk kehidupan (Daldjoeni, 1983, dan Wi-snubroto, 1999).

Ternyata anomali iklim dan pergeseran musim yang semakin meningkat, telah membingungkan para masyarakat petani dan budayawan yang masih mengharapkan konsep tradisional pranata mangsa bisa dihidupkan lagi. Pa-da kenyataannya bagi para petani yang tidak memiliki kemampuan mengantisipasi dan me-ngatasi kejadian anomali iklim dan pergeseran musim, akan semakin sulit meningkatkan taraf hidupnya (Boer, 2009). Dengan semakin majunya sistem pengamatan iklim global dan teknologi prakiraaan iklim, kemampuan untuk mem-perkirakan kejadian iklim ekstrem saat ini sudah sangat dapat diandalkan. Teknologi ini sudah mampu memprediksi dengan baik kondisi iklim suatu musim sejak 2 - 6 bulan sebelumnya. Na-mun, pemanfaatan informasi prakiraan iklim bagi petani untuk mengantisipasi kemungkinan terjadinya gagal panen masih sangat rendah. Salah satu metode yang dinilai cukup efektif ialah Sekolah Lapang Iklim (SLI) yang awalnya didesain Institut Pertanian Bogor (IPB) sejak tahun 2003. Tujuan SLI antara lain meningkatkan pengetahuan petani tentang iklim dan kemampuannya mengantisipasi kejadian iklim ekstrem, dengan materi SLI antara lain yaitu: konsep dasar prakiraan musim, pemanfaatan data historis kejadian banjir, kekeringan, dan kegagalan panen, pengenalan beberapa tek-nologi sederhana untuk mengatasi kekeringan seperti pemanenan air hujan, pemanfaatan infor-masi prakiraan iklim untuk menentukan strategi pola tanam dan rotasi tanaman, dan pendugaan nilai ekonomi informasi prakiraan iklim (Boer, 2009). Tantangan utama dalam SLI ini adalah cara menyampaikan informasi prakiraan iklim yang mudah dimengerti petani supaya mereka bisa memanfaatkannya untuk menyusun strategi budi daya dan langkah operasional lainnya. Di sinilah kemungkinan besar bahasa kearifan tradisional pranata mangsa bisa dimanfaatkan sebagai dasar pemahaman atau alat bantu bagi petani untuk masuk dalam meningkatkan pengetahuan petani tentang iklim dan kemampuannya mengantisipasi kejadian iklim ekstrem melalui SLI. Hal ini dapat dipergunakansebagai alasan untuk menghidup-kan kembali pranata mangsa di masa mendatang dengan konsep kekinian, yang dikombinasikan dengan ilmu pengetahuan modern, yaitu dengan memadukan kearifan tradisional dan teknologi masa kini.

\section{KESIMPULAN}

Pranata mangsa adalah kalender tra-disional dengan mangsa-mangsa yang memiliki pola berulang setiap tahunnya, ditetapkan oleh Sri Paduka Susuhunan Paku Buwono VII pada tan-ggal 22 Juni 1855 dari Kerajaan Surakarta sebagi kalender resmi pertanian di Pulau Jawa.

Walaupun secara fisik perubahan musim di bumi tidak berkaitan dengan kenampakan rasi bintang, karena jaraknya yang sangat jauh antara rasi bintang dan bumi, namun kenampakan pos-isinya yang relatif selalu tetap pada setiap mangsa dalam pranata mangsa, maka bintang-bintang tertentu dimanfaatkan sebagai petunjuk musim.

Pada zaman dahulu, banjir dan kekeringan telah ada, tetapi kemungkinan terjadinya peristiwa lingkungan terkait air tersebut dapat diprediksi jauh sebelumnya, sesuai seperti yang tertulis pada mangsa-mangsa tertentu dalam pranata mangsa.

Pada sekitar awal abad 19, ketika Thomas Stamford Raffles menjabat sebagai 
Letnan Gub-ernur, Pulau Jawa merupakan pulau yang subur dan makmur, dengan para petaninya yang memahami perihal siklus musim tradisional ber-dasar tanda-tanda alam, dan memanfaatkannya sebagai pedoman pertanian.

Sejarah zaman keemasan sampai pudarnya pranata mangsa, dapat dibagi dalam lima periode. Periode pertama sekitar tahun 1817 , ketika unsur-unsur pranata mangsa telah di-manfaatkan oleh petani untuk kegiatan pertaniannya. Periode kedua sekitar tahun 1855 ketika pranata mangsa ditetapkan oleh Sri Paduka Susuhunan Pakubuwono VII sebagai kalender resmi pertanian. Periode ketiga sekitar tahun 1920, ketika pranata mangsa mulai meleset dengan diketahui adanya anomali iklim. Periode keempat sekitar tahun 1970-an hingga tahun 1990-an ketika pem-bangunan infrastruktur di Pulau Jawa meningkat pesat, sehingga pranata mangsa banyak tidak tepatnya. Periode kelima sekitar tahun 2000 hi-ngga terakhir tahun 2016 ketika modernisasi kehidupan telah merata di Pulau Jawa dan pranata mangsa tidak lagi dihiraukan lagi sebagai kalender pertanian.

\section{SARAN}

Sebuah harapan bahwa budaya pranata mangsa dapat hidup kembali, yaitu bila konsep pembangunan dilakukan dengan basis keberlanjutan ekologi secara konsekwsen, dengan dukungan yang terintegrasi berupa "political will" dari pemerintah, "educational will" dari kalangan aka-demisi, dan "cultural will" dari masyarakat.

Keterpaduan kearifan tradisional pranata mangsa dengan teknologi modern prakiraan iklim diyakini dapat dimanfaatkan sebagai dasar pema-haman atau alat bantu bagi para petani untuk meningkatkan pengetahuannya tentang iklim dan kemampuannya mengantisipasi kejadian iklim ek-strim dengan bahasa petani tradisional melalui Sekolah Lapang Iklim.

\section{DAFTAR PUSTAKA}

263 | Jurnal Budaya Nusantara Vol. 2 No. 1
Badan Perencanaan Pembangunan Nasional (BAPPENAS), Badan Pusat Statistik (BPS), dan United Nations Population Fund (UNPF)

2013 Proyeksi Penduduk Indonesia, Indonesia Population Projection 2010-2035. Jakarta: Badan Pusat Statistik (BPS).

Boer, R.

2009 Sekolah Lapangan Iklim Antisipasi Risiko Perubahan Iklim. Jurnal Salam \#26 Januari 2009. http://www.agri-culturesnetwork.org/magazines/indonesia/26bertahan-menghadapi-perubahan-iklim/sekolah-lapan-iklim-antisipasi-risiko-perubahan/at_download/article_-pdf. [diakses pada tanggal 16 Agustus 2016].

Daldjoeni, N.

1983 Penanggalan Pertanian Jawa Pranatamangsa : Peranan Bioklimatologis dan Fungsi Sosiokulturalnya. Departemen Pe-ndidikan dan Kebudayaan, Badan Penelitian dan Pengembangan dan Ke-budayaan. Yogyakarta: Proyek Javanologi

Forest Watch Indonesia (FWI) dan Global Forest Watch (GWF)

2001 Potret Keadaan Hutan Indonesia. Bogor, Indonesia: Forest Watch Indonesia dan Washington D.C.: Global Forest Watch.

2014 Potret Keadaan Hutan Indonesia Periode 009-2013. Bogor, Indonesia: Forest Watch Indonesia.

Indrowuryanto

1999 Pranata Mangsa dalam Aktivitas Pertanian Di Jawa. Dalam: Petani Merajut Tradisi Era Globalisasi, Pendayagunaan Sistem Pengetahuan Lokal dalam Pembangunan. Adimihardja, K. ed. Bandung: Humanoria Utama Press. hal. 17-40.

Keraf, A.S.

2010 Etika Lingkungan Hidup. Jakarta: Penerbit Buku Kompas. ISBN: 978-979709-526-0. 
KOMPAS.com

2009 Ketika "Pranata Mangsa" Tak Lagi Bisa Dibaca....

http:// sains.kompas.com/read/2009/11 /10/10552170/ketika.pranata.mangsa.ta k.lagi.bi sa.dibaca... [diakses pada tanggal 16 Agustus 2016].

KPG (Kepustakaan Populer Gramedia) dan BBY (Bentara Budaya Yogyakarta)

2011 Seri Lawasan Pranata Mangsa. Khastiti, Y. L. (penyunting). Berdasar: Sindhunata dalam Katalog Pameran di BBY (Bentara Budaya Yogyakarta) 2009, Ana Dina Ana Upa: Pranata Mangsa. Jakarta: Percetakan Gramedia.

Provinsi Daerah Khusus Ibukota (DKI) Jakarta 1994 Peta Langit Malam untuk Daerah Sekitar Equator. Jakarta: Planetarium \& Observatorium. Dicetak kembali 2005.

Pusat Komunikasi Publik.

2012 Pulau Jawa Mengalami Water Stress. pu.go.id/main/view_pdf/7444.

https://www.google.co.id/?gws_rd=ssl

$\# \mathrm{q}=$ pulau+jawa+stress+air. [diakses pada tanggal 16 Agustus 2016].

Pusat Data dan Sistem Informasi Pertanian

2014 Statistik Lahan Pertanian Tahun 20092013. Sekretariat Jenderal. Kementerian Pertanian.

Raffles, T. S.

1817 The History of Java. Prasetyaningrum, E., N. Agustin, dan I.Q. Mahbuhah (alih bahasa). Simanjuntak, H., dan R.B. Santosa (penyunting). Yogyakarta: Nar-asi. 2008.

Simon, $\mathrm{H}$.

2001 Rancangan dan Prospek Pengelolaan Sumberdaya Hutan Pulau Jawa. Dalam: Prosiding Semiloka Menuju Pengelolaan Sumberdaya Hutan yang Lestari, Adil, dan Demokratis. Hutan Jawa Menjemput Ajal, Akankah Otonomi
Menjadi Solusi? Bakhtiar, I. dan Nugraheni, S.A.C. (peny-unting). Wonosobo: Temu Inisiatif DPRD SeJawa Madura.

Sobirin, Supardiyono.

2011 Menguak Tata Wayah.Disampaikan pada Obrolan Sabtu Sore. Dewan Pemerhati Kehutanan dan Lingkungan Tatar Sunda (DPKLTS). Bandung.

2011 Desain Sistem Penanggalan Nusantara Sebagai Kearifan Menapak Ke Depan. Disampaikan pada Seminar Mencari Format Kalender Nusantara di Gedung Merdeka. Bandung: Bengkel Studi Budaya.

Wardhana, Y.A.W., dan S. Sobirin.

2016 Kumpulan Wawancara Tentang Pranata Mangsa. Tim Peneliti Kalender Tradisional Pranata Mangsa untuk Kekeringan. Balai Hidrologi dan Tata Air, Pusat Litbang Sumber Daya Air.

Wikipedia

2015 Pranata Mangsa. Halaman terakhir diubah pada 25 September 2015, pukul 06.54. https://id.wikipedia.org/wiki/Pranata_mangsa. [diakses pada tanggal 16 Agustus 2016].

Wisnusubroto, $\mathrm{S}$.

1999 Pengenalan Waktu Tradisional Pranata Mangsa dan Wariga Menurut Jabaran Meteorologi, Manfaatnya Dalam Pertanian dan Sosial. Yogyakarta: Mitra Gama Widya.

Yulihastin, E.

2013 Mengapa Terjadi Kemarau Basah?. https://yulihastin.wordpress.com/2013/ 07/03/mengapa-terjadi-musim-kemarau/. [diakses pada tanggal 16 Agustus 2016]

Jurnal Budaya Nusantara Vol. 2 No. 1 | 264 